\title{
Limiting Terms of Office for Directors as a Policy Change in the Israeli Nursing System
}

\author{
Inga SHALEV ${ }^{1}$ \\ Adriana PRODAN ${ }^{2}$
}

\begin{abstract}
Background: This study examines the phenomenon of arrangements limiting terms of office for directors of nursing (DONs) as a policy change in the Israeli public healthcare system since nursing is a major component of the healthcare system's personnel, and DONs have a crucial influence on achieving the organization's goals in a changing and developing environment with limited resources.

Aim of Article: To understand how senior role-holders in the Israeli public healthcare system view arrangements limiting terms of office for directors of nursing as a policy change in the Israeli nursing system.

Methods: Qualitative design comprising face-to-face interviews with sixteen purposefully sampled senior managers at three medical centers in central Israel. Data were analyzed thematically.

Findings: Five themes emerged: ambivalence concerning the need for arrangements limiting terms of office, arrangements limiting terms of office as an organizational change, arrangements limiting terms of office as a method of career management, arrangements limiting terms of office - where they are headed, and length of the term of office.

Conclusions: This study shows that the answer to the question whether to perpetuate the past or shape the future is not unequivocal; it is evident from ambivalent attitudes towards the option of instituting arrangements limiting terms of office.
\end{abstract}

Keywords: Public healthcare system, nursing system, director of nursing, term limits, health policy, policy change, organizational change

JEL classifications: I15, M10, M12.

DOI: $10.24818 /$ RMCI.2018.2.109

\footnotetext{
${ }^{1}$ Inga Shalev, Edith Wolfson Academic Nursing School, Israel, Ph.D. student, Alexandru Ioan Cuza University of Iasi, Faculty of Economics and Business Administration, Iasi, Romania, ingashalev@wns.gov.il

${ }^{2}$ Adriana Prodan, Alexandru Ioan Cuza University of Iasi, Faculty of Economics and Business Administration, Iasi, Romania, pada@uaic.ro
} 


\section{Introduction}

\section{Background The nursing system}

Nursing in Israel is regulated by the Nursing Division of the Ministry of Health, which is responsible for initiating and supervising national nursing policy, including forecasting and planning nursing manpower needs (Ganz \& Toren, 2014; Greenberger, Haron \& Riba, 2014).

Two main trends have affected the nursing supply in Israel over the last two decades: (a) the addition of thousands of immigrant nurses to the profession as practical nurses, and the policy of Ministry of Health on retraining practical nurses licensed in Israel as RNs, as well as (b) the fact that practical nurses disappeared as thez have been trained since 2007, and registered as licensed nurses (since September 2009) after the recommendations of the Nursing Manpower Planning Committee (Nirel et al., 2012; Toren et al., 2012). This is compatible with the policy of workforce development aimed to train advanced academic RNs capable of bringing higher knowledge and skills to patient care.

\section{Nursing career tracks development}

The development of nursing career tracks takes place through advancement on a management, professional or dual (both) route (Toren \& Picker, 2009). Around the world, there are models of horizontal progression, based on the principles of a clinical promotion ladder. Most models of horizontal nursing career development rely solely on Benner's (2001) taxonomy, according to which knowledge and skills develop from a novice to an expert level. The 'clinical ladder' is a step-by-step system that allows career development, alongside salary increases by defining different clinical levels of nursing professional practice based on years of service, experience and knowledge.

Hierarchical promotion in hospitals mainly includes management roles. At department level, there are management positions ranging from team leader to charge nurse. At institutional level, there are management roles, some of which are lateral (research, human resources), and some are roles that consist of clinical supervision or managing decentralized systems. The head nurse - i.e. the director of nursing (DON) - heads an organization and is responsible for professional conduct and nursing conduct in the hospital. This role is the most senior nursing role in hospitals (Toren \& Picker, 2009).

\section{Directors of nursing (DONs)}

DONs are in a good position to bring about change in healthcare and in the quality of patient care due to their combined professional and managerial responsibilities (Talbert, 2012). DON is a central member of the hospital's administration responsible for most workers and budgetary expenses. This has occasioned an expansion of roles and responsibilities and an increase in expectations from DONs by other members of the administration. Krugman (1990) contended that these additional role demands require the DON to combine knowledge from nursing and business administration. Simms (1991) supported this

110 Review of International Comparative Management Volume 19, Issue 2, May 2018 
claim and stated that the DON's role requires "leadership skill and managerial competence linked with clinical nursing knowledge and research" (p. 37). Adams (1991) claimed that the expanded position requires a more comprehensive understanding of issues concerning the entire healthcare system. Therefore, nurse managers are now expected to acquire additional administrative and leadership skills.

\section{Literature Review}

\section{Organizational change and innovation}

Organizations undergo over time frequent changes. The dilemma facing organization leaders is: Should they maintain the stability of an organization and risk organizational antiquation, with all its negative consequences, or institute change and innovation and risk spinning out of control, which could lead to dissolution of the organization (Samuel, 2012)?

Since most of the significant changes that occur in organizations are an outcome of strategy, policy, and management decisions - organizational changes require systematic and controlled management (Graetz, 2010).

\section{The significance of innovation in public organizations}

Public organizations are responsible for carrying out operations that are important for the country's existence and for ensuring the well-being of its residents. Public organizations must develop alternatives to competition and profit motivations that spur the private sector to effect changes. One of the important roles of the management of all organizations that constitute their main responsibility is to see to constant evaluation of the organization and its improvement based on the findings. Moreover, stability is very attractive and it is an obstacle to innovation and change. For this reason, most organizations find it hard to adjust to changes offered as a solution to acute problems, and there is a clear tendency to prefer previous arrangements over innovations (Samuel, 2012; Todnem, 2005).

Systemic or organizational stagnation is the clearest characteristic of organizational decline and a sure warning for the danger of systemic collapse. There are many reasons for the decline of products, services, systems and organizations, such as technological changes, cultural changes, changes in market conditions, increasing global competition, demographic changes etc. There are also internal factors that contribute to organizational decline, such as: excessive confidence in one's way, over complacence, lack of control mechanisms, outdated information systems, lack of leadership, etc. Organizations that delay their response and postpone essential changes due to concerns, objection, blindness, disregard, etc. often reach a situation of organizational stagnation (Levy, 2008).

Statements that reflect this situation can be heard in organizations or systems in a state of stagnation. For instance: "Nothing happens here", "Full gas on neutral", "deep in the mud". This is a negative state for people facing it, however 
they remain where they are because any other state is perceived by them as worse. Situations of organizational stagnation are dysfunctional for the organization. They lead to lack of proper functioning and expenditure of energy, time and resources to handle the situation. Many managers reach a stage of saturation, and they perceive their managerial role as routine and lacking challenge. Setting terms of office and switching managers makes it possible to take new initiatives, deal with complex managerial problems, try non routine directions, risk opportunities, and prove their capabilities to the organizational environment - both external and internal (Graetz, 2010; Choi, 2011).

\section{The nature of policy change}

The nature of policy reforms and the organizations responsible for their implementation are by definition complex. Policy decisions and implementation tend to be highly political. Policy change addresses fundamental questions concerning what is to be done, how it is to be done, and how benefits are distributed. When change occurs, there are winners and losers. In order to implement a new policy, human, technical and financial resources must be allocated (Grindle, Merilee \& Thomas, 1990).

The inclusion of new tasks and objectives accompanying policy reform tends to generate modifications in the implementing organization. However, it is not easy to redesign or modify an organization. The existence of entrenched procedures and routines in bureaucratic organizations frequently arouses resistance to change in established organizations. Moreover, many organizational and management tasks required by reforms may be considerably different to the current ones (Crosby, 1996). Successful organizational implementation of policy change requires flexibility and creativity (Cerna, 2013).

\section{Term limits}

Definition - "Term limits are restrictions on how long a particular person can serve in an office. Term limits can be expressed in number of terms in office or years of service". Term limits are utilized so that a person cannot hold an office for life, thus letting a variety of people serve (Roberts, 2016).

\section{Arguments in favour of term limits}

Arguments supporting term limits include the contention that term limits are a healthy way to give to the organization new innovative ideas and energy. Using term limits, the organization can promise itself the range of skills and experience it needs. Term limits are also a good way of removing ineffective employees from the organization (Term limits, n.d.).

According to Summerville (2010), term limits are very important because organizations and institutions enjoy fresh ideas, energy, new capabilities and new relationships. Another good reason for term limits is that they compel organizations to develop new leaders (Moyers, 2011).

112 Review of International Comparative Management Volume 19, Issue 2, May 2018 


\section{Arguments against term limits}

A common argument against term limits is that they deprive an organization from the expertise and institutional memory. Others are concerned about the loss of engagement when an employee leaves the organization. Critics of term limits also mention that term limits result in the need to constantly recruit new employees (Bader et al., 2007; Orlikoff \& Totten, 2005; Moyers, 2011; Summerville, 2010). Another argument is that term limits are arbitrary and dangerous because they make valuable and experienced employees leave the organization (Orlikoff \& Totten, 2005).

\section{Terms limits for managers}

Previous studies and policy debates on the term length for directors have offered mixed findings. One view is that long-standing directors are more inclined to befriend managers, making them less effective at monitoring activities (Jia, 2016). Vafeas (2003), Byrd, Cooperman and Wolfe (2010), and Niu and Berberich (2015) find empirical evidence that supports this view. A contrasting argument is that directors who have been around for a long time acquire organization-specific knowledge and experience that result in greater commitment and competence. Dou, Sahgal and Zhang (2015) find supporting evidence that long-term directors are associated with tighter control and less organizational problems.

A major critique of long-term directors is that stagnant organizations that have many directors with extended terms do not refresh themselves, cannot keep current with technological developments and are unable to offer new insights (Jia, 2016). Prior management literature also notes that long executive terms are often associated with rigidity and commitment to established policies and practices that have the potential to repress the entrepreneurial spirit and hamper innovation (Tushman \& O'Reilly, 1997). March and March (1977) find that executives with short terms contribute fresh insights and are more willing to take risks that deviate from industry norms. Grusky (1963) suggests that short terms harm performance because replacement events disrupt well-established processes and generate instability and tension that harm performance. The disruptive nature of manager change is worsened by the loss of organizational specific knowledge (Greiner, Cummings \& Bhambri, 2002).

Life-cycle theories (Hambrick \& Fukutomi, 1991) suggest that a new manager develops new processes, a new team and a fresh strategy that improve long-term performance as they learn and make necessary adaptations. Although they suggest that managers over time become dysfunctional in an inverted Ushaped relationship with performance. Studies propose that organizational performance increases for the first 8-10 years but decreases subsequently as managers revert to utilizing old formulae (Miller \& Shamsie, 2001; Hughes et al. 2010). 


\section{Limiting terms of office for directors of nursing}

A considerable number of DONs at general government-run hospitals have been serving in this position for lengthy periods, some even for over fifteen years and some until they retire. This situation of lengthy terms of office and managers appointed 'for life' is likely to lead to a lack of professional development, burnout, high quality nurses leaving the government system due to lack of possible promotion, creating power points and lack of encouragement for excellence. Accordingly, this study examines whether the terms of office of DONs should be limited and which factors would be involved in arrangements limiting terms of office.

\section{Method of Research}

\section{Design}

This study, which is part of a larger mixed methods research, focuses on the first phase of the research, which utilizes a qualitative approach. Qualitative research is an approach used for exploring and understanding the meaning individuals or groups give to a social or human issue (Denzin \& Lincoln, 2003; Bryman, 2012; Creswell, 2014). The aim of this study was to explore the phenomenon of arrangements limiting terms of office for DONs in the Israeli public healthcare system as a policy change in the Israeli nursing system.

\section{Research participants}

The research participants consisted of 16 interviewees in senior management positions based on the following distribution:

1. At the Ministry of Health - the General Director of the Ministry of Health and the National Head Nurse were interviewed.

2. At three medical centres in central Israel - "stakeholders" were interviewed - the five most senior management officials in the healthcare system, as defined by the Civil Service Commission: the centre's CEO, deputy CEO, DON, administrative director, and CFO. In addition, charge nurses have been interviewed as they will reap the most benefit from this study and have the most to gain from it as a group.

\section{Sampling and sample size}

Purposive sampling strategies were implemented to enlist participants in semi-structured interviews. Another issue was that of saturation. According to Charmaz (2006), data collection was terminated when the categories or themes became saturated, i.e. when gathering fresh data no longer generated new insights or uncovered new properties. 


\section{Data collection tools}

Semi-structured interviews - one-on-one interviews conducted in person. A semi-structured interview guide was used for interviews, which were digitally recorded and transcribed for analysis by the researcher. The semi-structured indepth interviews conducted were aimed to present the range of views and perceptions presented by several senior management officials in the general hospital system. The interviews were held from August to November 2016. Each interview took 40-60 minutes, it was held in person at the interviewee's workplace and at a time of his or her choice. With one interviewee, a second session was held to clarify issues that had arisen in the interview. All the interviews were taken by the same interviewer.

Research journal - a written record of the researcher's activities, thoughts and feelings throughout the research process, from design to data collection and analysis to writing and presenting the study (Bloor \& Wood, 2011; Johnson, 2007; Silverman, 2005). This normally included comments on how the researcher felt, how the interview went and what the researcher felt throughout the interview, what the dominant themes were, non-verbal aspects of the interviewees' behaviour, as well as ideas about possible methodological and theoretical implications.

\section{Data analysis}

Content analysis was used in order to identify and describe patterns and themes from the perspective of participants. During data analysis, the data were organized categorically and chronologically, seeking recurring patterns, trends and useful conceptual categories, but room was also given to how things were said, and this revealed implicit contents (Creswell, 2014; Bryman, 2012; Shkedi, 2015). Specific attention was placed on the words and phrases used by participants to describe their opinions and views about limiting terms of office for DONs.

\section{Findings}

Interview data analysis yielded a descriptive summary of five indicatives: Ambivalence, Organizational change, Career management, Arrangements limiting terms of office - headed where? and length of the term of office.

\section{Ambivalence}

Ambivalence figuratively refers to the experience of two opposing forces and it is defined as simultaneously positive and negative orientations toward an object (Meyerson \& Scully, 1995). All the participants outlined a situation of mixed feelings and simultaneously contrasting views of limiting terms of office, leading to identification of the advantages and disadvantages of the studied phenomenon, a type of love and hate towards limiting terms of office. This is evident from the words of the DON (1), who said: "It's nice to have. It's very nice to say that you really really want it". While saying this, she smiled ironically (Research journal) and continued: "In principle, it can be very good, because in the 
long-term it is possible to see the disadvantages of remaining in a position for a very long time". This was supported by another DON (4), who said that "It's very important, because terms of office improve one's integrity and the decision making process, but the question is what will that DON do at the end of her term". Note that 4 did not consent to recording the interview. When asked why she refused, she said "I'm still working in the system and you can't know when I'll be quoted" (Research journal). A CFO (8) stated "It's essential because I believe in the law of diminishing marginal utility. It is necessary to bring in 'new blood'. It will revive all the young people who wish to advance, will encourage excellence, but the concern is that directors will proceed too quickly to show that they have done something, will be too quick to ascribe achievements to themselves and reap the benefits." Support for this opinion was provided by 6: "There's something logical in it. An opportunity for other people to do the job, but it is necessary to find another alternative position that preserves the same terms and status. The advantages are clear, but there are also disadvantages like achievements that can be lost, an organizational memory that is wasted."

In conclusion, ambivalence is described as having "mixed feelings", being "torn between conflicting impulses" and being "pulled in different directions."(Ashforth et al. 2014).

\section{Organizational change}

A need for change appears when the organization's functioning is not compatible with the expectations of the participants, their superiors or external elements that have an impact on the organization (Samuel, 2012). This is evident from the words of 1, who said that "there must be a dynamic of innovativeness, reinvigoration and development. When you are in the same position for a long time your thinking and work patterns become fixed. In summary, I shall say that limiting terms of office is good for everyone - good for the system, good for the teams, good for the official and of course best for the patients. On the bottom line, we are all in the hospital environment in order to give the patient's needs a better response." Support for this opinion was provided by 2: "The current situation does not enable the entrance of new forces and over the years the system becomes stagnated, does not develop and is not reinvigorated. In the long term, society is the one that loses from the current situation."

Therefore, we may note that when introducing arrangements limiting terms of office, which constitutes in effect a change, it is possible to encounter enthusiasm stemming from perception of the challenge involved and the opportunities for promotion and development that are formed, particularly as this is a change that benefits society (Samuel, 2012; Todnem, 2005). According to 3: "It will change something in the conception, in the dynamics, in the contents, in the centrality of things. And all these will make it possible to provide a better response to clients' needs". This was enhanced by 8: "It enables innovativeness - not to become stagnant. It does not hurt to be on the move."

116 Review of International Comparative Management Volume 19, Issue 2, May 2018 
The content analysis also shows that failure to innovate means stagnation, and stagnation in a rapidly changing world means regression. Among the conspicuous signs of stagnation is a lack of collaboration, and cooperation between the organization's components, poor practice and a low level of achievement, poor morale, the departure of skilled workers and difficulties with recruiting high standard personnel (Levy, 2008). According to 14, "It is important to preserve young high quality personnel who want to manage." This was enhanced by 7: "The terms of office model will make it possible to recruit potentials that at present are partially lost." 9 supported this: "I do believe that burnout overcomes innovativeness and the wish to be productive among managers who remain in the same position for 15 years." Extracting the organization from situations of stagnation requires a brave visionary leadership capable of building a new logic, uniting workers around it, and carrying it out (Graetz, 2010; Choi, 2011).

\section{Career management}

The content analysis uncovered the category of arrangements limiting terms of office as a method of career management. This is evident in the words of 1, who said: "There is a whole group of middle-rank leadership within the organization that, because it's stuck and has no opportunities for promotion, remains frustrated. Added to that, the higher you climb up the pyramid, the number of positions diminishes." Support for this opinion was provided by 2 who claimed that "If we move the pyramid, we shall have the privilege of replacing managers and on the way moving people and promoting them. She also added that it is very important to develop the management reserves in order to fill advanced managerial positions." Further support was provided by 3 who said "It is necessary to think about an outline of developing careers within an organization. Mainly, examining how to recruit good people to the organization's leadership. Among nurses, for example, the middle ranks feel very frustrated about being stuck with no promotion opportunities and that their only way of advancing is if the boss retires or resigns or something happens to him."

In conclusion, the main benefit attributed to the organizational career mechanism is ensuring greater fairness in the promotion system and reducing vagueness regarding possibilities of and demands for promotion. Planned career tracks require setting clear and uniform requirements for transition between roles (Bidwell \& Mollick, 2015).

\section{Arrangements limiting terms of office - headed where?}

Continuing category 4 , the content analysis uncovered the category of "Arrangements limiting terms of office - headed where?" One of the issues that most of the interviewees raised with regard to arrangements limiting terms of office is what alternatives does the director of nursing have when completing her term, particularly as this is a very senior position in the ladder of positions within the nursing system of the public healthcare system. As stated by 1 : "She can transfer to 
headquarters but even that is limited. She can manage the nursing system at another hospital, because it involves the need to deal with a new team, a different organizational culture, you can bring what you learned with you, what you did, to another place." This was supported by 2: "She can continue to another position in the hospital management that is not specifically connected to the nursing system, for example apply for the position of administrative director. She can of course go to the nursing administration."

All the above creates a picture showing that there are alternatives for additional positions after completing one's role as director of nursing. There are two alternatives: one is progress and movement upwards within the organizational hierarchy and the other is a sequence of functional experiences that constitutes horizontal movement within the organization. Support for the first alternative was provided by 6: "A person can't go backwards. You can't expect the Chief of Staff to become a foot soldier."

In summary, the issue of arrangements for limiting terms of office - where is it headed? has been perceived as a series of roles in which the occupational continuity enables hierarchic-vertical movement mainly upwards but also horizontal-functional (Bidwell \& Mollick, 2015).

\section{Term of office length}

Studies suggest that organizational performance increases for the first 8-10 years but decreases subsequently as managers revert to utilizing old formulae (Miller \& Shamsie, 2001; Hughes et al. 2010). However, Henderson, Miller and Hambrick (2006) suggest that this might depend on the nature of the industry. All the interviewees stated the same time range when defining the length of the term of office. They all said "five to six years". Moreover, they all cited the same explanation for this time range, saying that the first two years are devoted to learning the system, completing knowledge and gathering data. Then, you start to build a work plan and implement it and there is an expectation to see its products. 1 said: "In such a large system, by the time you learn the system and can realize some process of a work plan, you need this period of five years." This was reinforced by 2: "It takes at least three to four years until you understand the system and its needs and its model of development and only then do you form a strategy and a vision and create processes, it takes a long time." This was further supported by 3: "Five years is a reasonable time range in the Israeli context, as one of the problems in the Israeli circumstances is that there is no real national master plan for the healthcare system, from which plans can be derived for each hospital." 5 added: "It should not be too short a time so that one can lead a process, it must afford the minimal time to influence something. And not too long, to avoid burnout. The healthcare system is very complex and accumulating knowledge and experience takes at least four or five years."

Moreover, most of them were, on the one hand, in favour of the opportunity to extend the term of office while recommending not more than two terms. 3 said that "A reasonable term is five years with the option of extending for

118 Review of International Comparative Management

Volume 19, Issue 2, May 2018 
an additional period. You have to give enough time to someone who undertakes a senior management role so that the person can see the execution and implementation of things towards the end of the term. And if he was really good and did the job well, then you extend his term." 5 added that "No more than two terms because in this time you make the most of your abilities for the benefit of the organization and maintain its stability."

\section{Study Limitations}

Generalization of the conclusions can be claimed only regarding central Israel, although the findings are no doubt also relevant for other parts of Israel. The research began with a qualitative interview in order to obtain explanations about the studied phenomenon. The research will be continued with a quantitative, survey method using a large sample, so that the researcher be able generalize the results to entire population.

\section{Conclusions}

This study shows that the answer to the question whether to perpetuate the past or to shape the future is not unequivocal, it is evident from ambivalent attitudes towards the phenomenon studied. Limiting terms of office is a familiar social phenomenon and it provides the opportunity to implement private, social and organizational ambitions, but it also encompasses dangers and risks that arouse concern and thus a tendency towards rejection of the idea. In other words, the interviewees displayed a bivalent attitude towards the phenomenon of limiting terms of office - they declared that it is an important and essential principle for the system but expressed, both orally and in their body language, concerns of its implications. Since any change involves situations of uncertainty, the interviewees involved displayed a sense of tension, lack of confidence, and queries as to how the change would affect them.

Changes in the environment can be seen as a threat but also as an opportunity. Successful organizations encourage innovativeness, have a strong sense of mission and a wish to be an example of success over time. They invest many resources in promoting and developing human capital. They encourage risk taking and learning from mistakes. They encourage creativity and innovativeness and in fact create a new environment (Graetz, 2010; Samuel, 2012).

Many organizations tend to adhere to policy, procedures and tools proven efficient in the past, although in the present they must cope with completely different opportunities and threats. This is evident particularly in various governmental and public organizations that prevent turnover through arrangements of tenure, rights and benefits related to seniority and age, membership of pension funds, etc. As a result, workers or members of organizations show a constant aging trend, together with signs of old age and manifestations of fatigue described above. These senior older participants fight to maintain their status in the organization 
until they retire, despite accumulating burnout that eliminates their professional productivity. This phenomenon of degeneration is particularly conspicuous in information-rich organizations, in the health system, school system, welfare system etc. Extracting the organization from situations of stagnation requires a brave visionary leadership capable of building a new logic, uniting workers around it and carrying it out (Levy, 2008; Samuel, 2012).

Although the suggested policy change has been recognized as necessary and vital by many, it has also faced widespread opposition as it might involve serious costs. This new policy will probably require changes in attitude and actions. Because the policy constitutes a significant break from tradition, it is important that its advocates state that the new policy actually represents the preferred behaviour, that the policy is considered both valid and desirable. Furthermore, a successful organizational response for implementing policy change requires flexibility and creativity (Cerna, 2013).

It is important to realize that even though there is no clear answer concerning the need for limiting terms of office for directors of nursing and the attitudes towards this phenomenon are diverse, it is essential to keep an eye on the future and not remain in the past. Healthcare professionals must ensure that the managers who head the healthcare system are the most suitable and worthy over time. In addition, it is no less important to create a dynamics that enables personal and organizational development and refreshment of the system.

\section{References}

1. Ashforth, B.E., Rogers, K.M., Pratt, M.G., \& Pradies, C. 2014. Ambivalence in organizations: A multilevel approach. Organization Science. 25(5). 14531478 .

2. Adams, D., 1991. Management needs of head nurses and supervisors: designing a continuing education course. The Journal of Continuing Education in Nursing, 22(1), pp. 16-20.

3. Bader, B., Kazemek, E., Knecht, P. \& Witalis, R., 2007. Board member terms: to limit or not? [Online]. Retrieved from: https://static1. squarespace.com/static/5487509fe4b0672ae6c16f81/t/54a42123e4b0d132f64b 058a/1420042531511/Board_Members_Terms-To_Limit_or_Not.pdf [Accessed: 15 December 2016].

4. Benner, P., 2001. From novice to expert; excellence and power in clinical nursing practice. New Jersey: Prentice Hall Health.

5. Bidwell, M., \& Mollick, E. (2015). Shifts and ladders: Comparing the role of internal and external mobility in managerial careers. Organization Science. 26(6). 1629-1645.

6. Bloor, M., \& Wood, F., 2011. Keywords in qualitative methods: a vocabulary of research concepts. Thousand Oaks: Sage.

7. Bryman, A., 2012. Social research methods. $4^{\text {th }}$ ed. NY: Oxford.

120 Review of International Comparative Management

Volume 19, Issue 2, May 2018 
8. Byrd, J., Cooperman, E., \& Wolfe, G., 2010. Director tenure and the compensation of bank CEOs. Managerial Finance, 36, pp. 86-102.

9. Cerna, L., 2013. The nature of policy change and implementation: a review of different theoretical approaches. Organisation for Economic Cooperation and Development (OECD) Report. [Online]. Available from: https://pdfs.semanticscholar.org/15d8/a529d84b491b79d169aeabbfcb0532200 971.pdf [Accessed: 2 July 2017].

10. Charmaz, K., 2006. Constructing grounded theory. Thousand Oaks: Sage.

11. Choi, M., \& Ruona, W. E., 2011. Individual readiness for organizational change and its implications for human resource and organization development. Human Resource Development Review, 10(1), pp. 46-73.

12. Creswell, J., 2014. Research design; qualitative, quantitative, and mixed methods approaches. 4th ed. Los Angeles: Sage Publications.

13. Crosby, B. L., 1996. Organizational dimensions to the implementation of policy change. Monograph. New York: Management Systems International.

14. Denzin, N. \& Lincoln, Y., 2003. Introduction: the discipline and practice of qualitative research. In: N. Denzin \& Y. Lincoln, eds. Handbook of qualitative research. 2nd ed. London: Sage Publication, pp. 1-28.

15. Dou, Y., Sahgal, S., \& Zhang, E., 2015. Should independent directors have term limits? The role of experience in corporate governance. Financial Management, 44, pp. 583-621.

16. Ganz, F. D., \& Toren, O., 2014. Israeli nurse practice environment characteristics, retention, and job satisfaction. Israel Journal of Health Policy Research, 3(1), pp. 7-15.

17. Graetz, F., \& Smith, A. C., 2010. Managing organizational change: a philosophies of change approach. Journal of Change Management, 10(2), pp. 135-154.

18. Greenberger, C., Haron, Y. \& Riba, S., 2014. The Nursing Division of the Israeli Health Ministry moves nursing into the forefront of health care. Policy, Politics, \& Nursing Practice, 15(1-2), pp. 1-9.

19. Greiner, L., Cummings, T. \& Bhambri, A., 2002. When new CEOs succeed and fail: 4-D theory of strategic transformation. Organizational Dynamics, 32, pp. 1-17.

20. Grindle, M. \& Thomas, J., 1990. After the decision: implementing policy reforms in developing. World Development, 18(8), pp. 1176-78.

21. Grusky, O., 1963. Managerial succession and organizational effectiveness. American Journal of Sociology, 69, pp. 297-317.

22. Hambrick, D. C. \& Fukutomi, G. D. S., 1991. The seasons of a CEO's tenure. Academy of Management Review, 16, pp. 719-742.

23. Henderson, A. D., Miller, D. \& Hambrick, D. C., 2006. How quickly do CEOs become obsolete? Industry dynamism, CEO tenure, and company performance. Strategic Management Journal, 27, pp. 447-460. 
24. Hughes, M., Hughes, P., Mellahi, K., \& Guermat, C., 2010. Short-term versus long-term impact of managers: evidence from the football industry. British Journal of Management, 21(2), pp. 571-589.

25. Jia, N., 2016. Should directors have term limits? Evidence from corporate innovation. European Accounting Review, DOI: 10.1080/09638180. 2016.1199321.

26. Johnson, K.E., 2007. Tracing teacher and student learning in teacher-authored narratives. Teacher Development, 11, pp. 175-188.

27. Krugman, M. E., 1990. Nurse executive role socialization and occupational image. Nursing \& Health Care, 11(10), p. 526.

28. Levy, A., 2008. Management and leadership - change and innovation. Tel Aviv: Rimonim. (in Hebrew)

29. March, J. C., \& March, J. G., 1977. Almost random careers - the Wisconsin school superintendency 1940-1972. Administrative Science Quarterly, 22, pp. 377-409.

30. Marcus, A. \& Goodman, R., 1986. Airline deregulation: factors affecting the choice of firm political strategy. Policy Studies Journal, 15, pp. 231-246.

31. Meyerson DE, Scully MA., 1995. Tempered radicalism and the politics of ambivalence and change. Organ. Sci. 6(5):585-600.

32. Miller, D. \& Shamsie, J., 2001. Learning across the life cycle: experimentation and performance among the Hollywood studio heads. Strategic Management Journal, 22, pp. 725-745.

33. Moyers, R., 2011. Five reasons board leaders should have term limits. The Chronicle of Philanthropy [Online]. Retrieved from: https://www. philanthropy.com/article/Five-Reasons-Board-Leaders/190561 [Accessed: 15 December 2016].

34. Nirel, N., Riba, S., Reicher, S., \& Toren, O., 2012. Registered nurses in Israel - workforce employment characteristics and projected supply. Israel Journal of Health Policy Research, 1(1), p. 11.

35. Niu, F. \& Berberich, G., 2015. Director tenure and business and corporate governance. International Journal of Corporate Governance, 6, pp. 56-67.

36. Orlikoff, J. E. \& Totten, M. K., 2005. Term limits for board members. Term limits on board service can help keep boards fresh and effective. Healthcare Executive, 20(3), pp. 60-70.

37. Roberts, M., 2016. Term limit. The Balance [Online]. Retrieved from: https://www.thebalance.com/term-limits-1669489 [Accessed: 15 December 2016].

38. Samuel, Y., 2012. Organizations: introduction to the Theory of Organizations. Or Yehuda: Zmora-Bitan-Modan (in Hebrew).

39. Shkedi, A., 2015. Words of meaning. Qualitative research - theory and practice. Tel Aviv: Ramot Publications, Tel Aviv University (in Hebrew).

40. Silverman, D., 2005. Doing qualitative research: a practical handbook. London: Sage Publications.

122 Review of International Comparative Management Volume 19, Issue 2, May 2018 
41. Simms, L. M., 1991. The professional practice of nursing administration: integrated nursing practice. Journal of Nursing Administration, 21(5), pp. 37-46.

42. Summerville, M. W., 2010. The leadership challenge of term limits. Trusteeship Magazine [Online]. Retrieved from: https://www.agb.org/ trusteeship/2010/mayjune/the-leadership-challenge-of-term-limits [Accessed: 15 December 2016].

43. Talbert, T., 2012. The role of the nurse executive in fostering and empowering the advanced practice registered nurse. The Nursing Clinics of North America, 4(2), pp. 261-267.

44. Term limits, n.d. [Online]. Retrieved from: https://www.agb.org /briefs/term-limits [Accessed: 15 December 2016].

45. Todnem By, R., 2005. Organisational change management: a critical review. Journal of Change Management, 5(4), pp. 369-380.

46. Toren, O., \& Picker, O., eds., 2009. Leadership in white. Managing nursing in hospitals. Jerusalem: Magnes (in Hebrew).

47. Toren, O., Zelker, R., Lipschuetz, M., Riba, S., Reicher, S., \& Nirel, N., 2012. Turnover of registered nurses in Israel: characteristics and predictors. Health policy, 105(2), pp. 203-213.

48. Tushman, M. \& O'Reilly, C., 1997. Winning through innovation: a practical guide to leading organizational change and renewal. Boston, MA: Harvard Business School Press.

49. Vafeas, N., 2003. Length of board tenure and outside director independence. Journal of Business Finance and Accounting, 30, pp. 1043-1064. 